\title{
Da Educação e da Literatura
}

A edição no. 30 da Revista Dialogia, Educação e Literatura, traz uma entrevista com o poeta, ensaísta e professor Clóvis Da Rolt. Entre tantas outras coisas que poderiam ser destacadas, o professor enfatiza a importância da literatura enquanto uma ferramenta feroz de abertura para novos saberes, assim como o aspecto interdisciplinar que a leitura possibilita em todos os graus. Não deixa de observar o quanto as escolas, em geral, na maioria das vezes, esquecem que a literatura deveria ser um verdadeiro suporte para se repensar novas formas de existência, experiências.

No dossiê destacamos o texto Drummond e o engajamento literário em que a autora analisa o olhar social do poeta mineiro, tendo como fundamentação teórica Sartre, no que diz respeito da literatura, intrinsecamente, estar comprometida com a sociedade de sua época, ao mesmo tempo em que contrapõe Merleau-Ponty sob um olhar diferente, ou seja, a partir do interior da obra poética. As poéticas de cuidado com o meio ambiente na literatura infantil e juvenil brasileira possibilita um diálogo esclarecedor no que diz respeito aos cuidados que os tempos atuais exigem da humanidade por meio de narrativas dirigidas ao público infantil.

O artigo Entre margens: Guimarães Rosa na Sala de Aula é uma contribuição valiosa no que diz respeito à literatura. A proposta dos autores é analisar o famoso conto do autor mineiro "A Terceira Margem do Rio" enquanto uma leitura introdutória de Guimarães para o ensino médio. Nessa medida, destaca o quanto uma literatura universal e de real valor pode ser possível, inclusive, para aqueles que estão em fase de amadurecimento, para outras leituras do autor, assim como para aquelas leituras que precisam de um repertório para compreender a poética literária. O texto Ensino de História, Planejamento e Autoria: experimentações com literatura negra em estágios curriculares obrigatórios faz uma análise significativa ao analisar o papel do professor autor. Ou seja, propõe que as aulas de história dialoguem com as teorias propostas pela área juntamente com a literatura que foca o negro em estágios curriculares obrigatórios entre história e culturas africanas. Cecília Meireles e sua atuação política na educação brasileira: Literatura, Jornalismo e Feminisno é um artigo faz uma análise detalhada entre a vida e formação da escritora. Desta maneira, evidencia o legado que conjuga literatura, política e educação.

Os artigos que se seguem ao dossiê analisam diferentes questões de grande interesse para a área da Educação. Note-se a importante contribuição de Flavia Iuspa Correio da 
Florida International University. A pesquisadora destaca, entre outras coisas, questões de perspectivas múltiplas para encontrar soluções efetivas diante de problemas globais. Há uma análise de experiências internacionais de aprendizado que estende nossa consciência a respeito da diversidade cultural que povoa o globo. O texto $O$ potencial transformador da arte: um diálogo entre Vigotski e Antonio Candido faz uma análise importante sobre o papel transformador da arte ao mostrar o quanto a estética humaniza e adensa os sentidos.

Escola e interculturalidade: elementos para pensar a diversidade no currículo pode ser uma perspectiva diferenciada e mais abrangente para se refletir a educação dentro de um sistema global capitalista. Nessa medida, o artigo contraria o famoso discurso etnocêntrico. Vamos brincar na terra? Uma experiência de valorizaçãa e resgate da cultura infantil com moradores da comunidade de Arraiol na Amazônia Amapaense é um texto que discute o brincar ribeirinho na comunidade de Arraiol. Demonstra o quanto as brincadeiras infantis são importantes para compreender as crianças e o quanto as práticas sociais influenciam o comportamento das mesmas.

A escolha profissional na perspectiva do Estudante do Ensino Técnico de Nivel Médio é significativo, à medida que abre um espaço de reflexão, de caráter qualitativo, para professores que lecionam a estudantes de ensino médio. Rompendo os muros escolares possui como tema central a discussão dos processos educacionais escolares levando em consideração a reflexão sobre as práticas pedagógicas monoculturais e hegemônicas. Por um currículo plural na perspectiva do multiculturalismo é um texto que tem como centro a discussão do conceito de multiculturalismo. Neste artigo há uma reflexão significativa que envolve, inclusive, a formação de professores.

A resenha da coletânea Formação de Professores no Brasil: leituras a contrapelo reúne textos de pesquisadores ligados ao Grupo de Estudos sobre Política Educacional e Trabalho da Universidade Federal de Santa Catarina.

Boa leitura a todos, Ana Maria Haddad Baptista

Márcia Fusaro

as editoras 